\title{
Evolution of luxury marketing landscape: a bibliometric analysis and future directions
}

\author{
Rubal Rathi ${ }^{1}$ (D) $\cdot$ Ruchi Garg $^{1} \cdot$ Aakanksha Kataria $^{1} \cdot$ Ritu Chhikara $^{1}$
}

Revised: 5 January 2022 / Accepted: 13 January 2022 / Published online: 2 February 2022

(c) The Author(s), under exclusive licence to Springer Nature Limited 2022

\begin{abstract}
The concept of luxury is archaic, but it is only recently that luxury marketing (LM) has caught academic attention. The result is a growth in global publications. This study examines 34 years of scientific research on LM through bibliometric and content analysis of Scopus data consisting of 893 articles from 271 journals. Results reveal that though the field is still developing, it has been approached from multiple disciplines and methodologies. A structured bibliometric and content analysis enabled an in-depth study of the field's evolution. Further, the results of bibliographic coupling indicate clusters of emerging themes in LM scholarship such as sustainability, social media marketing, counterfeiting, among others. Finally, a conceptual framework emerging from the thematic clusters and future research directions follow.
\end{abstract}

Keywords Bibliometric analysis $\cdot$ Luxury marketing $\cdot$ Luxury research $\cdot$ Luxury branding $\cdot$ Luxury marketing strategy · Bibliographic coupling

\section{Introduction}

The global luxury industry is radically changing and experiencing colossal growth. This transformation is not restricted to Europe and the West anymore and has entered Asian markets. This lucrative industry is expected to reach a whopping $\$ 1.5$ trillion market across categories by 2025 (Matter of Form 2019). Luxury brands consequently leave no stone unturned to meet growing consumer expectations. A surge in academic interest is also observed where close to 50 percent of articles on LM have appeared since 2017, compared to the past three decades.

Luxury is not a novel concept. It is rather a centuriesold notion, only evolving in meaning and perception. In the seventeenth century, luxury was restricted to extraordinary commodities like rare pearls and crystals. The nineteenth and twentieth centuries brought a deeper understanding of craftsmanship and customization, invoking dreams, uniqueness, and exclusivity (Berthon et al. 2009). Research in the

Rubal Rathi

rubal.rathi.19pd@bmu.edu.in

Ritu Chhikara

ritu.chhikara@bmu.edu.in

1 BML Munjal University Campus, NH-8, Gurugram, Haryana 122413, India last quarter of the twentieth century focused on historical perspective (Berry 1994) and economic outlook (Chao and Schor 1998). Subsequent research, however, expanded in scope and investigative themes evolved to consumer behavior (Kastanakis and Balabanis 2012), cross-cultural comparisons (Shukla 2010), provenance effects (Liu et al. 2016), counterfeit market (Nia and Zaichkowsky 2000), etc. Publications are coming to the fore, and journals introduce special issues to capture existing and emerging trends, signifying researchers, and practitioners' seriousness in this area.

LM research has witnessed a drastic change in the past decade. Academic developments and a global outlook on environmental protection, luxury, and sustainability converged (Kapferer and Michaut 2020). More scholarly attention deviated toward digitalization (Jain and Shultz 2019) and usage of smart technologies, which most luxury brands earlier eschewed. Today, luxury means more than materialistic possessions, and themes like experiential luxury (Batat 2019), hedonic escapism (Holmqvist et al. 2020), liquid luxury (Bardhi et al. 2020) have gained the spotlight as Gen $\mathrm{Z}$ are the new luxury consumers. For them, 'access' outweighs 'ownership'. Consequently, attempts to capture new meanings and formulate definitions are ongoing (Becker et al. 2018; Ko et al. 2019).

This study complements the influential work of Gurzki and Woisetschläger (2017). Being a prominent bibliometric 
Table 1 Comparison of previous studies with the present study

\begin{tabular}{|c|c|c|c|}
\hline Basis for comparison & Gurzki and Woisetschläger (2017) & Aliyev and Wagner (2018) & Our study \\
\hline Time period & $2000-2015$ & 2000-2016 & $1986-2020$ \\
\hline Keywords & $\begin{array}{l}\text { Luxury, conspicuous consumption, } \\
\text { status consumption, prestige brand, } \\
\text { status brand }\end{array}$ & $\begin{array}{l}\text { Luxury goods, luxury brands, luxury } \\
\text { perception, and attitudes toward } \\
\text { luxury }\end{array}$ & $\begin{array}{l}\text { Luxury good, luxury market, luxury } \\
\text { brand, luxury consumption, luxury } \\
\text { marketing strategy, status consump- } \\
\text { tion, prestige brand, status brand }\end{array}$ \\
\hline Focus of the study & Luxury research across disciplines & Luxury brand marketing research & Luxury marketing research \\
\hline Methodology & Co-citation and cluster analysis & Content analysis & $\begin{array}{l}\text { Bibliographic coupling, thematic } \\
\text { analysis, citation analysis, content } \\
\text { analysis }\end{array}$ \\
\hline Papers referred & 1315 & 242 & 893 \\
\hline Database & ISI Web of Knowledge & Science Direct, ProQuest, JSTOR & Scopus \\
\hline Conceptual framework & Yes & No & Yes \\
\hline
\end{tabular}

work on luxury, it significantly contributes to the literature with an exhaustive interdisciplinary 15-year review. However, since 2015, luxury research has developed dramatically with new and influential themes. This study reviews 34 years of luxury literature ending 2020, which witnessed a drastic surge in publications. It also explains the most recent LM research and myriad themes with a robust methodology while paving the way for meaningful future research. In another recent review based on a sample of 242 articles from 2000 to 2016, Aliyev and Wagner (2018) performed qualitative and bibliometric analyses. Contrarily, this study reviews a larger sample size of 893 articles as a part of core analyses (Refer Table 1). Limiting the sample can implicate the rigor and depth, seriously impacting the results and contributions.

LM can be one of the most fertile research areas in the marketing realm considering its preponderance in varied disciplines. Existing reviews have probed into the manifestation of underlying luxury concepts, but none encompasses the latent conceptual and intellectual configuration of emerging research themes. To bridge this gap and address previous studies' limitations, this review adopts an integrative approach to generate new knowledge by analyzing extant literature rather than simply providing a descriptive and historical overview (Sydner 2019). Through an integrative review, we aim to propose the preliminary conceptualizations of emerging research areas and advance the scholarship with a theoretical framework resulting from bibliographic coupling, content analysis, and thematic analysis.

We extend a deep dive into intellectual concepts of both consumer and brand behavior while focusing on other aspects crucial to this contemporary niche by addressing the following research questions:

RQ 1 What is the current publication trend, most influential articles, and journals in LM?
RQ 2 What is the intellectual structure of current research? How can that be woven into a conceptual framework?

RQ 3 Which research trends dominate LM, and where is the field advancing? What are the potential areas for future research?

The paper is structured as follows. First, the research methodology section introduces the data retrieval and analysis process. Subsequently, the analysis and findings section presents the research trends and prominent journals. It further maps different clusters emerging from bibliographic coupling for articles until 2019. Further, content analysis is presented for the 2020 scholarship. Next, the conceptual framework based on cluster themes is proposed. Lastly, the discussion section summarizes the research findings and concludes by providing implications for theory, practice, and limitations.

\section{Methodology}

\section{Search strategy and data retrieval process}

Three-stage data retrieval, selection, and analysis process were followed to identify relevant studies (Fig. 1). The first stage defined the research objectives. Keyword selection followed. An ideal search strategy for such analysis must be broad in scope, covering comprehensive themes. Thus, the retrieval process expanded beyond "luxury" and included "luxury good," "luxury market," "luxury brand," "luxury consumption," "luxury marketing strategy," "status consumption," "prestige brand," and "status brand" as keywords. To ensure the validity of search terms, we consulted a panel of scholars and received feedback affirming their usability (Zupic and Cater 2015). 


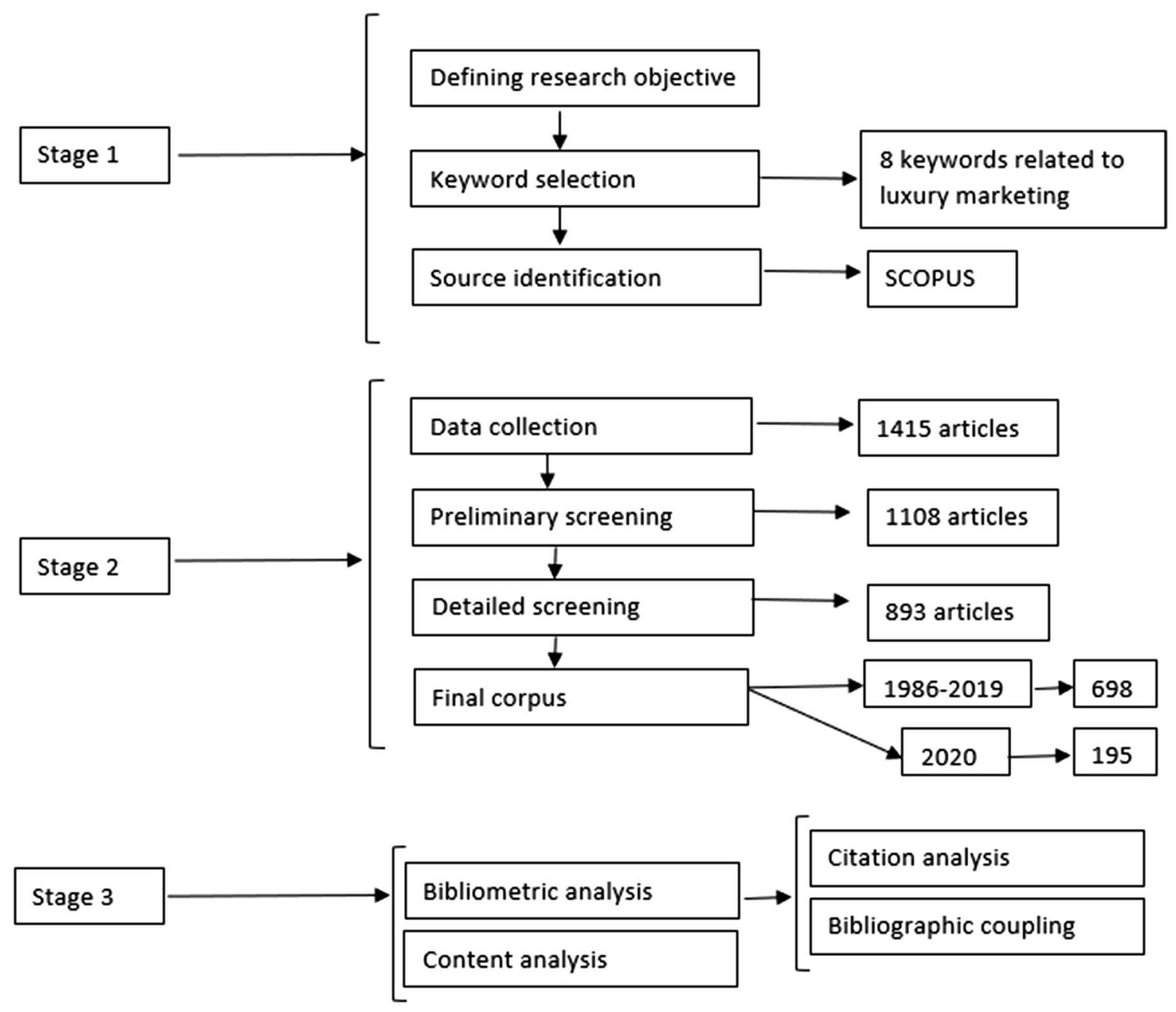

Fig. 1 Flowchart of the methodology

Next, a data retrieval source was identified. Scopus online database that reveals a comprehensive picture of a database and extracts unique citations compared to Web of Science (WoS) and Google Scholar (AlRyalat et al. 2019), providing broader coverage of journals than WoS (Block and Fisch 2020), was used to retrieve relevant articles. Scopus is an established and trustworthy database for bibliometric analysis globally as it not only presents metadata records but curates author profiles and abstracts from journals, conference proceedings, and book series (Baas et al. 2020). The database was retrieved on 5 June 2021 and returned seminal articles for 34 years from 1986 to 2020. Articles in the late 1990s and early 2000s are few but prominent as extant literature.

\section{Research method and analysis}

The second stage comprises four key steps leading to the final corpus. The preliminary search yielded 1415 documents. Next, all the articles were screened for relevance.
Irrelevant articles that did not fit into the inquiry area were removed by examining the title and keywords, resulting in 1108 documents. Subsequently, for final screening, keywords, abstracts, and full papers were scrutinized manually to remove articles beyond the scope of LM. The parameters for inclusion and exclusion of articles are mentioned in Table 2. This resulted in 893 documents forming the final corpus.

Bibliometric analysis, a qualitative and quantitative technique, is an exponentially growing research method globally as it allows researchers to access each other's contributions in an area (Roig-Tierno et al. 2017). With its introduction in 1969 as a statistical and modeling tool (Pritchard 1969), bibliometric analysis today has advanced to present a detailed view of a research field by concisely mapping the trends enabling researchers to draw meaningful insights. Scholars have adopted this technique to map contemporary marketing topics like digital communication and IoT (Kim et al. 2019; Miskiewicz 2020). It has further been used to explore marketing journals' research activities (Donthu et al. 2020). 
Table 2 Inclusion and exclusion criteria of articles

\begin{tabular}{ll}
\hline Basis & Description \\
\hline $\begin{array}{l}\text { Inclusion criteria } \\
\text { Source }\end{array}$ & Articles from peer-reviewed journals \\
Type of article & Empirical studies, review articles, meta-analytic studies \\
Language & English \\
Subject area & Business, management \& accounting, social sciences \\
Exclusion criteria & \\
Type of article & Comments, book reviews, book chapters, conference papers, reports \\
Keywords & Keywords used in a context beyond the scope of this study \\
\hline
\end{tabular}

This study employs bibliometric techniques to map the LM research landscape, followed by a most recent scholarship content analysis. As we observed a drastic growth in the articles published in 2020, a separate content analysis was performed to gather deeper insights on 195 articles from 2020. After identifying the chronological structure, its intellectual core was investigated using bibliographic coupling. The analysis was performed using (Visualization of Similarity) VOSviewer, which succinctly maps the area graphically and eases interpretation (Kruggel et al. 2020).

\section{Analysis and results}

\section{Trends in LM research}

A timeline analysis captures total publications spread across 1986 and 2020 (Fig. 2). It depicts a dearth of LM research until 2008 and a spike moving forward. Following the Great Recession, the sharp increase might correspond to more industry and academic attention to the luxury industry. This substantial growth results from a booming global luxury industry, thriving new markets like Asia, evolving consumer segments with greater purchasing power like millennials and Gen Z. Interestingly, 37\% of the corpus' total research took place in 2019-2020, with 195 articles (28\%) in 2020 alone, signifying growing academic interest.

\section{Research outlets}

The 893 articles occurred in 271 journals (Table 3). Journal of Business Research (JBR) leads with 102 articles, followed by Journal of Brand Management (59 articles). The prominence of LM persuades journals to introduce special issues addressing contemporary topics. $J B R$ alone publishes an average of 2016.5 articles annually on luxury through special issues (Khan et al. in press, p. 308). Interestingly, journals from various disciplines like fashion management, retailing, consumer marketing, psychology, and logistics publish on LM, making it a topic of interest.

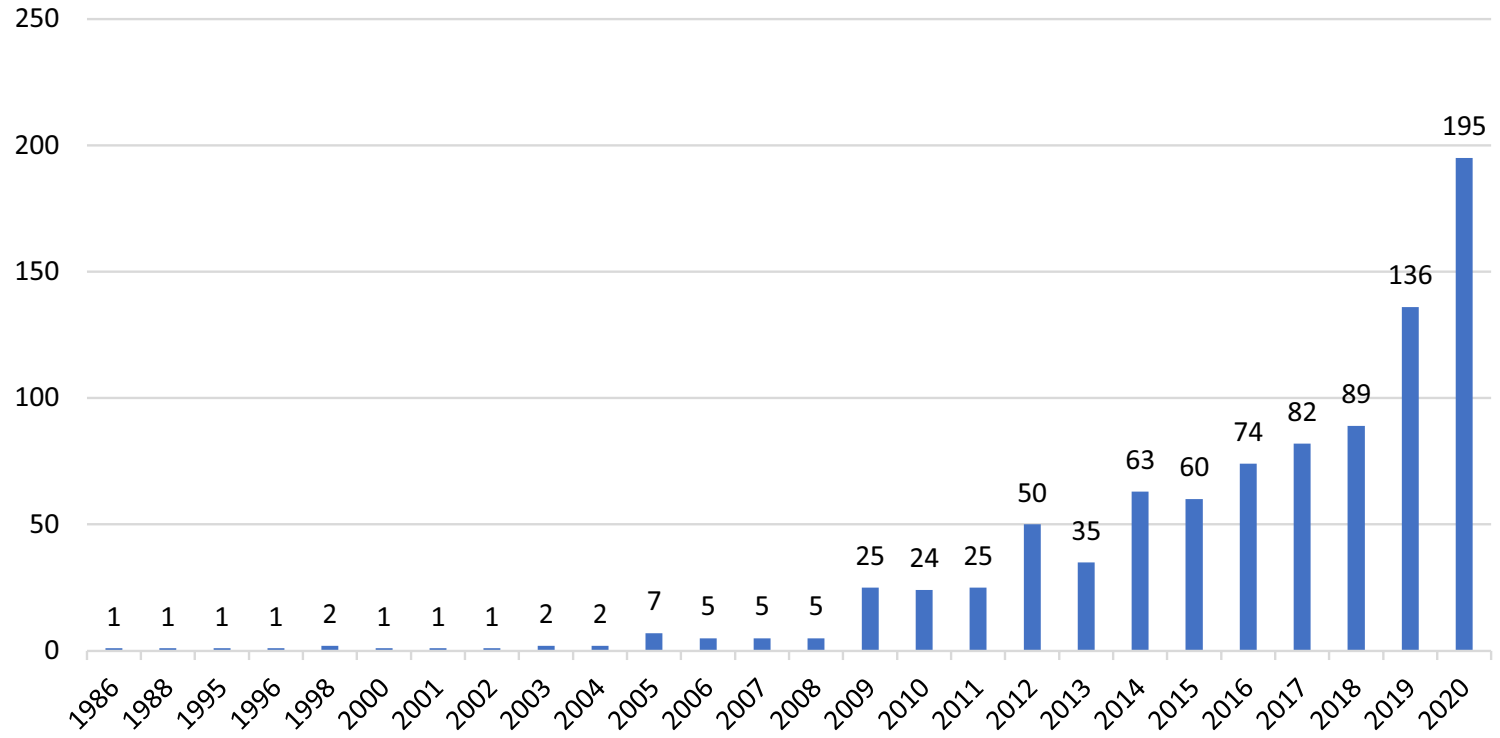

Fig. 2 A chronological view of luxury marketing research 
Table 3 Top 10 contributing Journals

\begin{tabular}{lll}
\hline Name of the Journal & Publishing house & $\begin{array}{l}\text { Num- } \\
\text { ber of } \\
\text { articles }\end{array}$ \\
\hline Journal of Business Research & & 102 \\
Journal of Brand Management & Elsevier & 59 \\
Journal of Fashion Marketing and Management & Palgrave & 59 \\
Journal of Retailing and Consumer Services & Emerald & 54 \\
Journal of Global Fashion Marketing & Elsevier & 36 \\
Journal of Product and Brand Management & Taylor and Francis & 29 \\
Psychology and Marketing & Emerald & 22 \\
International Journal of Retail and Distribution Management & Wiley & 20 \\
Journal of International Consumer Marketing & Haworth Press & 18 \\
Asia Pacific Journal of Marketing and Logistics & Emerald & 20 \\
\hline
\end{tabular}

\section{Mapping the intellectual structure of LM: thematic analysis of articles from 1986-2019}

The thematic structure derived through bibliographic coupling establishes central themes in the corpus. Documents creating a bibliographic couple demonstrate a similar intellectual structure (Weinberg 1974). The VOSviewer software divided the corpus into eight thematic clusters. The output is based on link strength between articles calculated through the count of common references (Wallin 2005). The first seven clusters cover $99.3 \%$ of articles and only those are discussed. Table 4 outlines the central theme and leading articles for each cluster. We suggest future research areas along with each cluster, later tabulated as future research questions ("Appendix 1").

Cluster 1-Conceptualizations and Responsible luxury is the largest cluster covering 24\% (169 of 698) publications and second largest with $20 \%$ (3639 of 18,172) citations. It is divided into two broad thematic areas. First, research diverted toward the meaning of luxury, where researchers attempted to operationalize and measure luxury by providing definitions and revisiting scales like Brand Luxury Index (BLI) (Vigneron and Johnson 2004; Miller and Mills 2012). The core of opulence has been providing unmatched customer experiences, as reflected in the highest cited papers (Tynan et al. 2010; Atwal 2017). While the highest cited articles discuss the value and experiential luxury, the contemporary discourse has shifted to a more sustainable approach to luxury.

This second area started accelerating from 2012 when international organizations like the United Nations opened dialogues around sustainability. A decade ago, luxury was only about ostentatious products, but with pressure on brands to be socially conscious, much research explored a match between the two. As a result, themes like sustainability, Corporate Social Responsibility (CSR) (Ki and Kim
2016; Jin 2017), and the ethical outlook of these elite brands have gained momentum (Karatzas et al. 2019).

Sustainability and luxury are considered oxymorons, but research finds evidence of an intersection (Woodside 2019). From a business perspective, luxury brands are becoming proactive toward their environmental standpoint (Mititelu et al. 2014) and leveraging their associations with charity and non-profit organizations (Boenigk 2015) to a strategic advantage for brand prominence and positioning (Baghi and Gabrielli 2018). From a consumer's perspective, research has moved to a newer generation-the millennials (Rolling and Sadachar 2018). They demand their favorite brands to behave responsibly and ethically while maintaining the aura of luxury (Brysen et al. 2013). Regarding theoretical frameworks, articles in this cluster use many theories, the most prominent being Self-Determination theory.

With the emergence of shared business models and collaborative consumption, we expect future research to focus on (1) consumer risk perceptions while using collaborative consumption applications; (2) identifying cross-cultural consumer motivations beyond western consumers; (3) the inherent mismatch between CSR and luxury, identifying strategies that work and do not work for luxury brands; (4) scale development on sustainable aspects of luxury. Theoretical research has set the tone for the meaning of sustainable luxury, attempts toward scale development might be interesting; (5) subjects like minimalism and simplistic luxury experiences that new-age consumers value. Additionally, the new luxury meaning relating to mindful consumption and happiness has immense potential for investigation.

Cluster 2-Luxury consumer behavior has 19\% (134) publications and the highest citations of $27 \%$ (4852). Predominantly, research on consumer culture, values, demographics, and psychographics dates to 1998 and is ongoing with evolution in themes. The highest cited article (1382 citations) relates to cultural aspects of luxury consumption 
Table 4 Luxury marketing cluster overview

\begin{tabular}{|c|c|c|c|c|c|c|c|}
\hline \multirow[t]{2}{*}{ Cluster } & \multirow[t]{2}{*}{ No. of papers } & \multirow[t]{2}{*}{ Central focus } & \multirow[t]{2}{*}{ Major topics explored } & \multirow[t]{2}{*}{ Starting year } & \multirow[t]{2}{*}{ Ending year } & \multicolumn{2}{|l|}{ Top 3 cited papers } \\
\hline & & & & & & Author(s) (Year) & Citations \\
\hline \multirow[t]{3}{*}{ Cluster 1} & \multirow[t]{3}{*}{169} & \multirow[t]{3}{*}{ Responsible luxury } & \multirow{3}{*}{$\begin{array}{l}\text { Sustainability, CSR, } \\
\text { responsible con- } \\
\text { sumption, ethical } \\
\text { consumption, sharing } \\
\text { economy, cause-related } \\
\text { marketing, meaning } \\
\text { and definition, scale } \\
\text { development, concep- } \\
\text { tualization }\end{array}$} & \multirow[t]{3}{*}{2005} & \multirow[t]{3}{*}{2020} & Tynan et al. (2010) & 903 \\
\hline & & & & & & $\begin{array}{l}\text { Atwal and Williams } \\
\text { (2017) }\end{array}$ & 881 \\
\hline & & & & & & $\begin{array}{l}\text { Kapferer and Bastien } \\
\text { (2017) }\end{array}$ & 829 \\
\hline \multirow[t]{3}{*}{ Cluster 2} & \multirow[t]{3}{*}{134} & \multirow[t]{3}{*}{$\begin{array}{l}\text { Luxury consumer } \\
\text { behavior }\end{array}$} & \multirow{3}{*}{$\begin{array}{l}\text { Consumer-related fac- } \\
\text { tors, socio-cultural } \\
\text { impact, segmentation }\end{array}$} & \multirow[t]{3}{*}{1998} & \multirow[t]{3}{*}{2020} & $\begin{array}{l}\text { Wong and Ahuvia } \\
\text { (1998) }\end{array}$ & 1382 \\
\hline & & & & & & Wiedmann et al. (2009) & 1012 \\
\hline & & & & & & O'Cass and Frost (2002) & 857 \\
\hline \multirow[t]{3}{*}{ Cluster 3} & \multirow[t]{3}{*}{115} & \multirow{3}{*}{$\begin{array}{l}\text { Luxury brand manage- } \\
\text { ment }\end{array}$} & \multirow{3}{*}{$\begin{array}{l}\text { Brand meaning, brand } \\
\text { elements, branding } \\
\text { strategies, Brand- } \\
\text { related factors }\end{array}$} & \multirow[t]{3}{*}{2004} & \multirow[t]{3}{*}{2020} & Berthon et al. (2009) & 629 \\
\hline & & & & & & Monga and John (2010) & 360 \\
\hline & & & & & & Torelli et al. (2012) & 355 \\
\hline \multirow[t]{3}{*}{ Cluster 4} & \multirow[t]{3}{*}{90} & \multirow{3}{*}{$\begin{array}{l}\text { Luxury social media } \\
\text { marketing }\end{array}$} & \multirow{3}{*}{$\begin{array}{l}\text { Social media, brand } \\
\text { community, customer } \\
\text { brand relationships, } \\
\text { online engagement, } \\
\text { co-creation }\end{array}$} & \multirow[t]{3}{*}{2010} & \multirow[t]{3}{*}{2020} & Kim and Ko (2012) & 2133 \\
\hline & & & & & & Godey et al. (2016) & 736 \\
\hline & & & & & & Kim and Ko (2012) & 599 \\
\hline \multirow[t]{3}{*}{ Cluster 5} & \multirow[t]{3}{*}{89} & \multirow[t]{3}{*}{$\begin{array}{l}\text { Conspicuous consump- } \\
\text { tion }\end{array}$} & $\begin{array}{l}\text { Luxury consumption, } \\
\text { status consumption, }\end{array}$ & 2004 & 2020 & $\begin{array}{l}\text { Nelissen and Meijers } \\
\text { (2011) }\end{array}$ & 489 \\
\hline & & & gender, tourism, and & & & Garín-Mun (2006) & 349 \\
\hline & & & hospitality & & & Üstüner and Holt (2010) & 391 \\
\hline Cluster 6 & 58 & Customer perceived & Customer motivation, & 2003 & 2020 & Hung et al. (2011) & 394 \\
\hline & & value & perception, experience, & & & Choo et al. (2012) & 288 \\
\hline & & & $\begin{array}{l}\text { cross-cultural value } \\
\text { perceptions }\end{array}$ & & & $\begin{array}{l}\text { Prayag and Hosany } \\
\text { (2014) }\end{array}$ & 222 \\
\hline Cluster 7 & 57 & Counterfeiting & Ethical aspects, motives & 2000 & 2020 & Wilcox et al. (2009) & 993 \\
\hline & & & $\begin{array}{l}\text { and rationale, moral } \\
\text { aspects }\end{array}$ & & & $\begin{array}{l}\text { Nia and Zaichkowsky } \\
\text { (2000) }\end{array}$ & 972 \\
\hline & & & & & & $\begin{array}{l}\text { Bian and Forsythe } \\
\text { (2016) }\end{array}$ & 692 \\
\hline
\end{tabular}

in the West (Wong and Ahuvia 1998). Wiedman (2009) and O'Cass and Frost (2002) are other highly cited articles. These discuss brand association and value-based aspects of luxury consumers who view luxury through a lens of symbolism. They also draw a cultural perspective to understand luxury consumption in western and Confucian societies.

This cluster closely associates consumer-related attributes, covering psychological, personal, and cultural aspects. Broadly classified as consumer perception-related factors, their orientation toward luxury (Chao and Schor 1998); perceived brand status (O'Cass and Siahtiri 2014); value perceptions and attitudes (Arli et al. 2016) are discussed. Psychological factors like the need for uniqueness ( $\mathrm{Yu}$ and Sapp 2019); subjective well-being (Hudders and Pandelaere 2012); motivation (Truong and McColl 2011) are highly emerging and recurrent themes. Cultural facets of consumer behavior corresponding to the effect of culture and religion on attitude formation and cross-cultural comparisons are also significant (Yim et al. 2014). With luxury democratization and reasonably priced premium products for the middle-class, themes like masstige (Truong et al. 2009) also emerged but were not rigorously carried forward. Digital and online commerce are other recently experienced phenomena (Madinga et al. 2016). Young consumers are adept at online shopping modes adding to their extended digital self (Jain 2018). Conspicuous signaling theory is the most used theoretical framework in this cluster.

With consumer-based factors shaping this cluster, future research is expected to focus on (1) the diverse demographics within Asia. Differences between East and West have been studied, but a comparative, cross-cultural analysis across China, Korea, India can provide an Asian perspective; 
(2) luxury products have been discussed at length; however, consumer attitudes toward luxury services have little research support. The only evidence has stemmed from the tourism industry. Other services like luxury dining, private jet, wine matching, etc., that provide unmatched experiences have a great scope of academic investigation; (3) new business models offering pre-loved luxury items that cater to a newer segment of luxury consumers. Acceptance of secondhand luxury can be investigated across generations and cultures.

Cluster 3-Luxury brand management with 16\% (115) publications and 10\% (1871) citations- encapsulates branding-related themes. The top-cited article (Berthon et al. 2009) condenses three values constituting a luxury brandfunctional, experiential, and symbolic. Other heavily cited articles-Torelli et al. (2012) and Monga and John (2010) lay foundations for luxury brand meanings and pave the way to appreciate brand concepts and extensions. Brand meaning (Oswald 2010) and strategies (Keller 2017) significantly cover this cluster where brand extension (Reddy et al. 2009), line extensions (Boisvert and Ashill 2018), and co-branding (Wang et al. 2015) are dominant. More recently, as digital platforms are expediting, virtual image strategies have gained significance (Jin and Ryu 2019). Brand elements like identity (Heine et al. 2018), personality and image (Adomaitis and Saiki 2019), communication (Gurzki et al. 2019), positioning (Bartikowski et al. 2019) are noteworthy. Associative network theory and construal level theory are most prominent in this cluster.

Recent research in this cluster is seen to have shifted to digital aspects of luxury branding. Therefore, we expect future research to consider: (1) the implications of digital branding for heritage luxury brands with different value sets; (2) digital interaction between brands and consumers would mean more intelligent strategies for customer engagement through digital touchpoints. This should encourage scholars to formulate online luxury communication strategies; (3) in an omnichannel environment where each touchpoint demands unmatched experience, it is worth exploring how brands create seamless and integrated customer journeys; (4) collaborations are not new to luxury. However, academic backing is scant. Researchers must formulate models for luxury brands to adopt while collaborating, especially in distinct product categories (luxury and sports brand collaboration); (5) Technological advances are shifting the global luxury consumer culture. It is critical for brands to maintain stewardship. Cultural studies in this context would be worthwhile.

Cluster 4-Luxury social media marketing has 13\% (90) publications and $15 \%$ (2717) citations. The central theme driving this cluster is the social media marketing efforts of luxury brands. Although luxury is believed to be a lethargic adopter of technology, brands in the digital age leave no stone unturned to connect with their consumers. With the arrival of social media, research in this cluster started in 2010 and has escalated since then. Moving forward, social media will be a crucial topic for research as the new generation is tech-savvy and connects more with brands with an online presence.

These pros of the internet and social media also hold a contrary view. While social media strengthens a brand's relationship with potential customers, it also posits a dilemma of maintaining the aura of luxury and perception of rarity and antiquity. As a result, brands face a constant need to balance their connection with the masses yet preserve the extravagance for a happy few (Kapferer and Bastien 2017). This cluster grounds in uses and gratification theory the most.

Despite challenges, marketing through social media has become the most popular channel; thus, we expect future research to consider (1) what strategies from traditional marketing do not fit the online strategy; (2) in an era of digitalization where smart technologies using AR, VR, IoT are gaining popularity, it will be interesting to know how these technologies catalyze the social media presence and associations with consumers; (3) the impact of online celebrity endorsements on consumer-brand connect; (4) the COVID-19 pandemic has augmented digital platforms, and live streaming is a new normal. Therefore, investigations from brand and consumer perspectives on the double-edged nature of live streaming would be interesting.

Cluster 5-Conspicuous consumption covers 13\% (89) publications, and 11\% (2047) citations. A consumption pattern where consumers indulge intending to exhibit status, this cluster emerged initially in 1986 but accelerated from 2004. Research on social comparison and status signaling has been the oldest field in the entire corpus. The highest cited articles unfold two distinct areas.

Nelissen and Meijers (2011) examined luxury brands' social benefits while signaling wealth and status. Üstüner and Holt (2010) laid theoretical foundations for status consumption in less industrialized nations by explaining how status is not restricted to the West. Garín-Mun (2006), on the other hand, investigated the Canary Islands as a potential luxury destination basis the cost of travel, signaling tourists' status and wealth.

Research is persistent with the abovementioned themes, with some evolution over time. Deriving from Garın-Munoz (2006), much research followed luxury tourism as a signal of opulence (Serra et al. 2014). This sets the tone for luxury service research. Another theme following the corpus' oldest article (Andrus et al. 1986) relates to luxury gifting to showcase richness and wealth (Chen and Kim 2013). Costly signaling theory dominates this cluster.

Considering these themes, future research is expected to (1) explore how consumers display conspicuousness while consuming intangible services like luxury dining or spa; 
(2) conspicuousness has been understood and appreciated, but the role of inconspicuous luxury still requires academic investigation; (3) similarly, it would be interesting to note the role of minimalism and spiritual luxury.

Cluster 6-Customer perceived value covers $8 \%$ (58) articles and 6\% (1120) citations. Research in this cluster started in 2003 but elevated after 2010. The central theme is customer motivation and intangible value derived from luxury consumption. Due to its subjective nature, it becomes vital to study what value means to different customers. The highest cited article (Iglesias et al. 2011) discusses the relationship between consumer identity and purchase intention. These stem from the intangible perceived value during a luxury purchase. Other highly cited articles examine value perceptions in services (Prayag and Hosany 2014) and conceptualize luxury value influenced by behavioral intention and brand relationships (Choo et al. 2012).

The concept of value has matured over the years. Individual value perceptions (Brun et al. 2015) have expanded to social identity (Gentina et al. 2016). The corpus suggests that value varies across customers and brands, extending functional and symbolic benefits (Heine 2010). Further, the latest view of value has set the floor for a sustainable and environmental perspective (Dogan-Sudas et al. 2019). Most articles use the Theory of Planned Behavior (TPB).

In the last decade, value has emerged as an important theme with plenty of scope for further investigation. Pertinent topics for future research include (1) value perceptions for new luxuries are studied, but little research supports change in value perceptions while purchasing secondhand luxury; (2) the meaning of value perceptions for luxury services and rentals have been underexplored.

Cluster 7-Counterfeiting covers 8\% (57) publications and $10 \%$ (1887) citations, yet critical for academicians and practitioners. The highest cited article sets the ground for consumer motives and rationale behind buying counterfeit luxury products. Research on counterfeiting augmented in 2009 and has been continuing since then. Other highly cited articles explored perceptions and attitudes of the owners of original luxury products and whether counterfeits devalue their ownership of authentic luxury (Nia and Zaichkowsky 2000), besides the unethical side of indulging in fake purchases (Bian et al. 2016). In the later part of the last decade, authors examined cultural and social perceptions of counterfeit purchases (Wang et al. 2019) extrapolated into studying brand and consumer-related factors (Aksoy and Abdulfatai 2019) across cultures. Dominant theoretical frameworks include TPB and Theory of Reasoned Action.

Considering the legal and moral importance of this cluster, we expect future research to focus on (1) the coping mechanisms of luxury brands when facing fake products; (2) consumer knowledge and awareness regarding authenticity in third-party online channels; (3) generational studies and their reaction to counterfeits, as Gen $\mathrm{Y}$ and $\mathrm{Z}$ are more aware consumers.

\section{Most recent work in LM scholarship: analysis of $\mathbf{2 0 2 0}$ articles}

The year 2020 reflects a rise in LM scholarship and comprises $28 \%$ of the total corpus. We thereby present a separate content analysis of 195 articles from 2020, extraction of which followed similar methods as the bibliometric analysis. While the overarching themes remain similar, many new sub-themes emerged:

- Aside from various aspects in consumption behavior like the impact of logos on consumers (Peng et al., 2020), bandwagon effect (Mainolfi 2020), religiosity (Arli et al. 2020), prominent research on luxury advertising, and communication (Kim et al. 2020) emerged.

- Unlike previous years, 2020 witnessed a surge in luxury services research across industries-tourism (Correia et al. 2020), service experience at restaurants (Peng, 2020), online purchase behavior for hotels (Banerjee and Pal 2020) being at the forefront.

- Another dominant area sprouted from the cultural impact in emerging economies, specifically the Asia Pacific region (Das 2020).

- Gender has emerged as a moderator in multiple studies, e.g., exploring whether luxury gifting entails similar meaning for men and women (Ding et al. 2020).

- New business models in sharing economy (Jain and Mishra 2020) and collaborative consumption (Pantano and Stylos 2020) have surfaced, focusing on experiences more than possessions.

- Research on digital buying behavior (Fazeli 2020) also experienced an upward trend.

Following an epistemological perspective (Aliyev and Wagner 2018), we evaluated 195 articles from 2020 to understand the theoretical grounding of LM concepts. A total of 74 articles consisting of 66 unique theories were identified through keyword search and in-depth manual screening. The remaining 121 articles did not explicitly refer to any theory. We manually evaluated each article carefully and rigorously as theoretical frameworks are not outright visible through keyword searches in most cases.

We identify the dominant theoretical frameworks intersecting both bibliographic coupling and content analysis. Theory of Planned Behavior (Jain 2020), Self-Determination Theory (Hasbullah et al. 2020), and Signaling Theory (Jebarajakirthy et al. 2020) are mostly used in the entire corpus. Few articles use more than two theoretical underpinnings, e.g., acculturation and social cognitive theory (Das and Jebarajakirthy 2020), cognitive dissonance, balance and 
masstige theory (Jhamb et al. 2020), cue utilization and categorization theory (Kim et al. 2020). As most studies concern consumer behavior, theoretical foundations derived through bibliographic coupling and content analysis find an intersection. Theories laid with cultural impact (consumer culture theory), consumer attitude (attitude theory; functional attitude theory), and social representation of consumption (Baudrillard's critical social theory; social cognitive theory) as background are prominent. With bandwagon and snob effects dominating luxury consumption behavior and self and social relationships acting as reference points, research has been grounded in social comparison theory (Loureiro et al. 2020), self-expansion theory (Nyadzayo et al. 2020), social adaptation theory (Park and Yim 2020), and social judgment theory (Teona et al. 2020). Additionally, as emerging research introduces technology as a critical aspect and uses network data, social network analysis (Blasi et al. 2020) and task-technology fit theory (Kusumasondjaja 2019) have gained importance.

Luxury research is no longer geographically and categorically confined with an observed outgrowth of crosscultural studies. Moreover, the diversity extends to generational cohorts where millennials and Gen $\mathrm{Z}$ are increasingly becoming the locus of upcoming research. A consolidated snapshot of its cross-cultural, cross-generational, and multisector presence is presented in Figs. 3 and 4.

\section{Conceptual framework}

Adding further depth to the analysis, a conceptual framework is developed based on the thematic clusters. The model dimensions lay theoretical foundations for the concepts otherwise studied in isolation and present them under a broad umbrella of LM. The cluster strength discussed in the previous section is based on reference commonality. However, some themes occur in more than one cluster in different contexts, signifying cluster interconnectedness.

The conceptual model (Fig. 5) presents the co-existence of brands and consumers. This ecosystem is deep-rooted into philosophical perspectives opening a horizon for society's macro inclusion. At the core of LM, ecosystem is a belief that brands and consumers interact to co-create value through luxury brand experiences. Consumer-brand relationships prove that luxury brands are more than just names, signs, and symbols (Hodge et al. 2015), and value is cocreated by nurturing these relationships.

Brands strive toward achieving a competitive advantage (Kotler et al. 1994), the highest level of which is reached by forming brand communities where consumers form subcultures representative of their passion for the brand (Wright et al. 2006). These engagement activities have been offline in the past, but with the recent emergence of digitalization
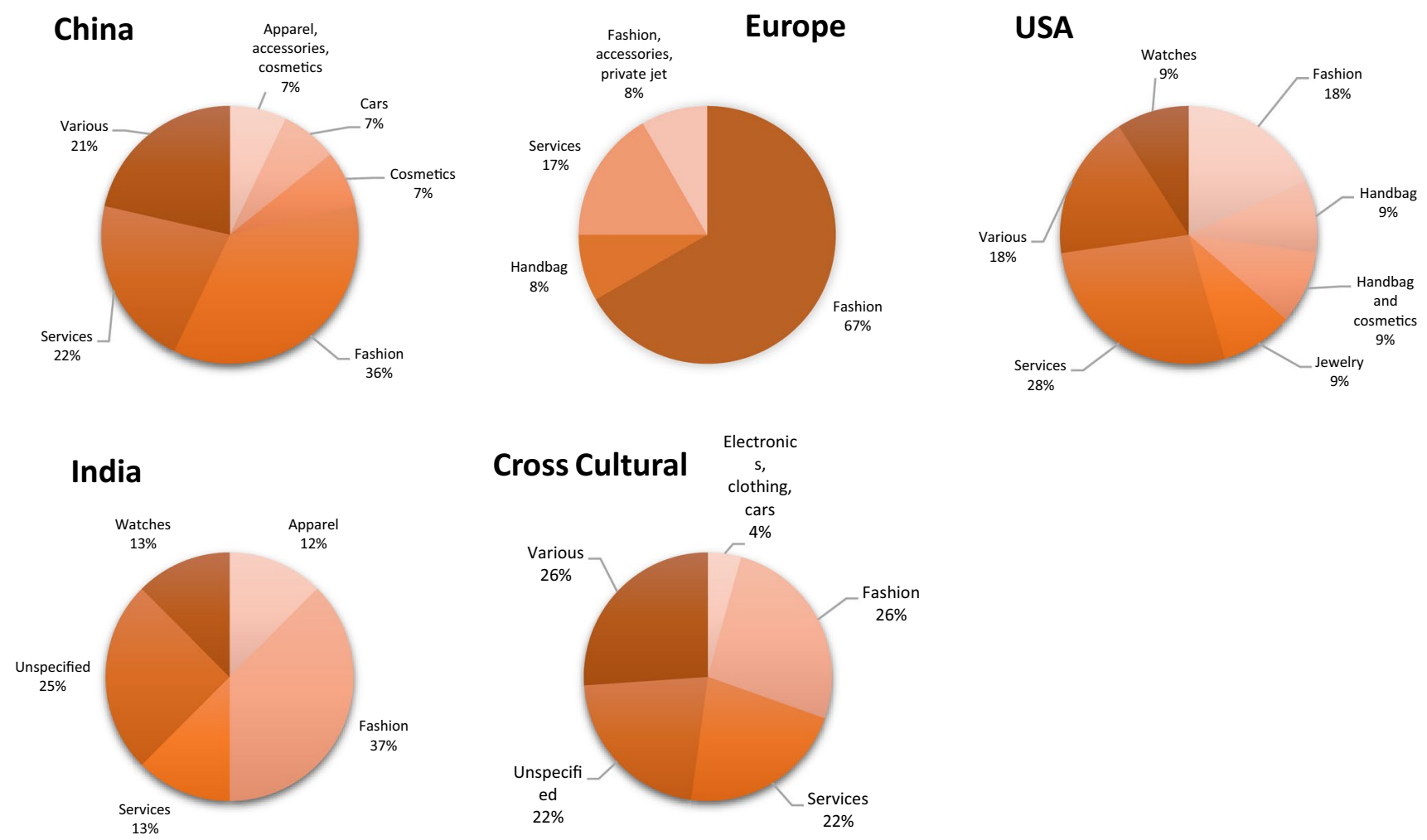

Fig. 3 Country-wise representation 

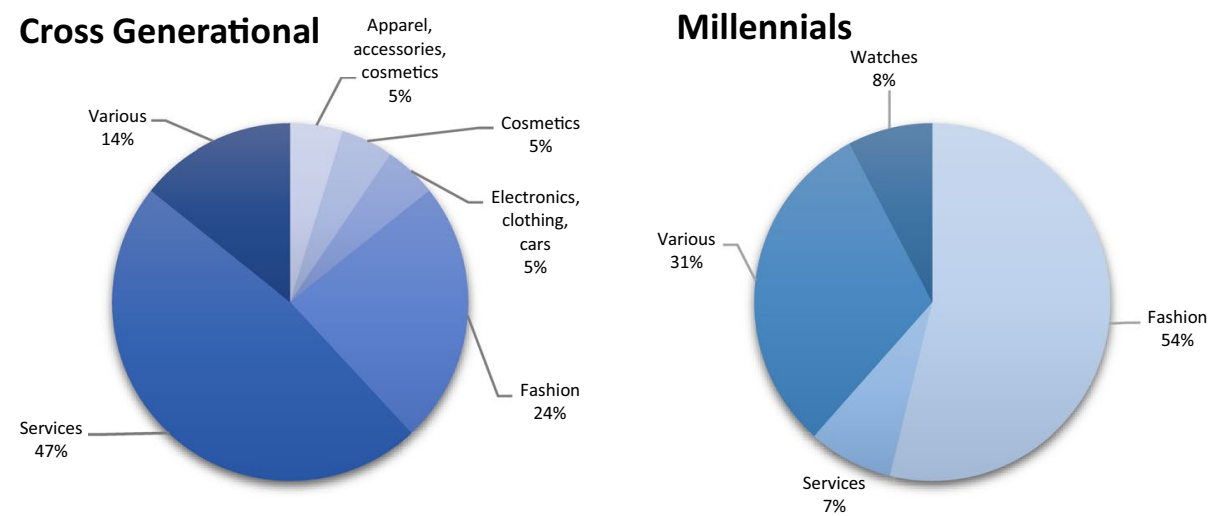

Millennials and Gen Z

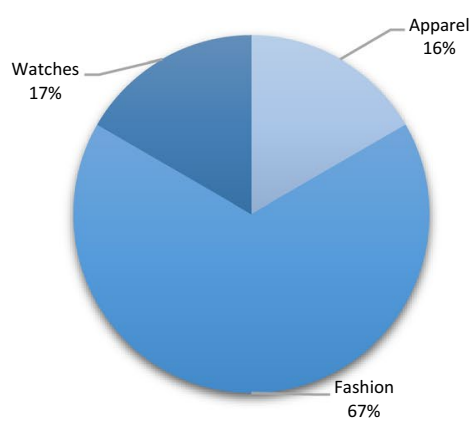

Fig. 4 Generation-wise representation

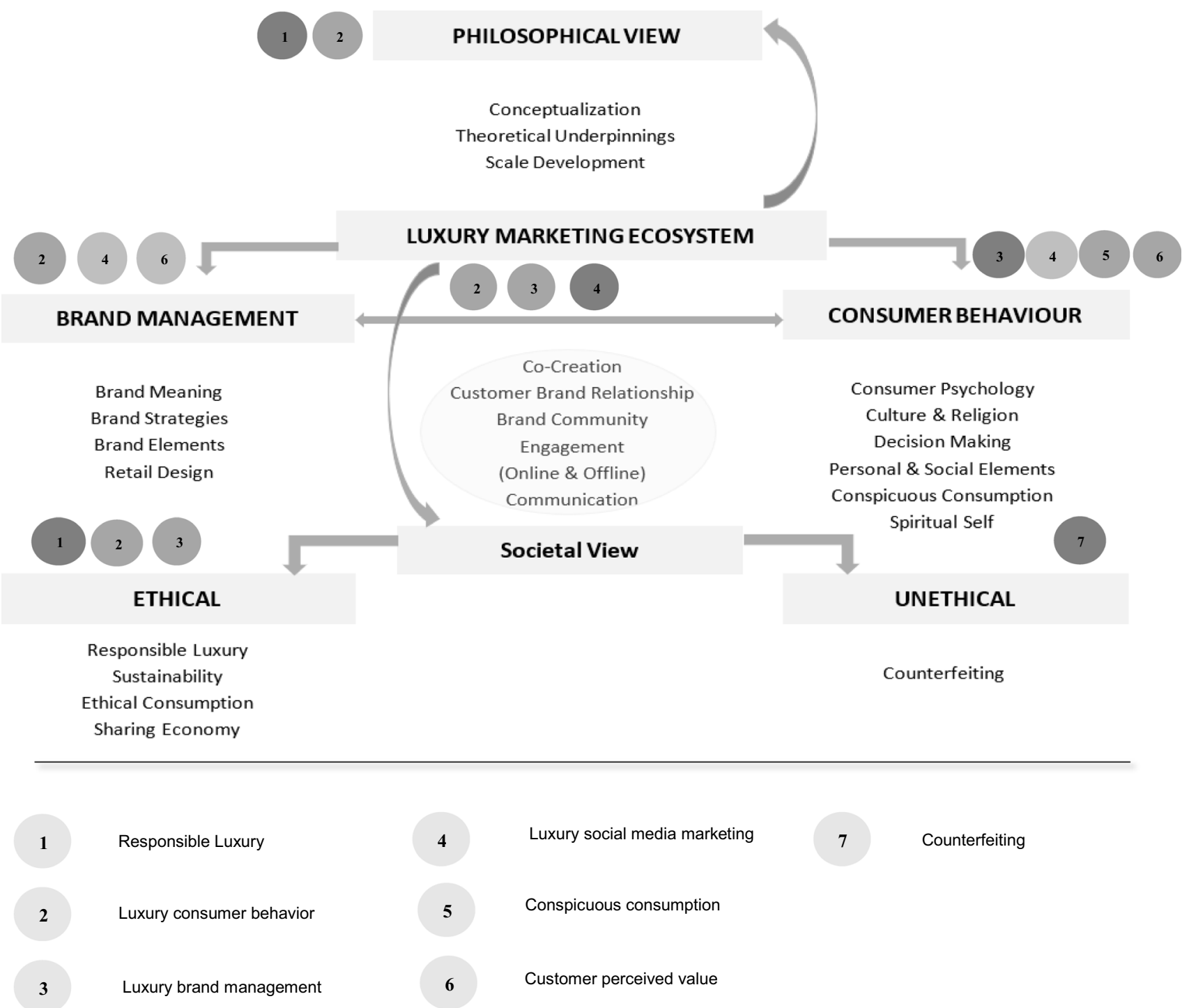

Fig. 5 Conceptual Model

售: 
and social media, brands leverage the internet to improve engagement. As consumers actively participate in this communication, brands' role is no more of 'controlling knowledge structures,' and consumers are no longer 'passive absorbers of brand knowledge' (Gensler et al. 2013, p. 243).

Recent brand management research studied growth strategies for luxury brands (Keller 2017), brand equity and performance (Guzmán et al. 2009), mergers and acquisitions (Štrach and Everett 2006), country-of-origin effects (Coudounaris 2018), and introducing communication through advertisements (Massara et al. 2020) across product categories and industries like luxury automobile (Tournois and Chanaron 2018), fashion (Skorobogatykh et al. 2014), watches (Donzé 2020), wines and spirits (Taplin 2016).

Another major focal point is consumer behavior. Significant literature analyzed cultural aspects in luxury consumption (Wong and Ahuvia 1998), where consumer psychology (Shukla 2010) behind conspicuous consumption (O'cass and Frost 2002) was studied at length. In addition, many generational studies have emerged, making Gen $\mathrm{Y}$ and $\mathrm{Z}$ as new luxury consumers (Grotts and Johnson 2013). This segment has also brought new perceptions and motivations (Kastanakis and Balabanis 2012) in their decision-making processes (Audrin et al. 2018), and is bent toward spirituality (Ngai and Cho 2012).

The seven clusters indicate the field's progress and suggest pre-existing themes that have progressed in their contribution capacity and are being discussed in global luxury research. One such area relates to conceptualizing LM's philosophical structure. Attempts to propose operational definitions have been rigorous (Miller and Mills 2012; Becker et al. 2018). These theoretical underpinnings have set the ground for more in-depth investigations into exploring brand and consumer perspectives like the specificity of managing luxury brands (Kapferer and Bastien 2017) or consumer discourse on consumption (Roper et al. 2013).

Vast research has laid importance on the societal view of LM broadly covering the industry's bright and dark sides. Many ethical aspects are attributed to responsible consumption and cause-related marketing (Mititelu et al. 2014), sensitizing brands and consumers toward sustainability (Pencarelli et al. 2020), creating a discourse on sharing economy (Jain and Mishra 2020). Contrarily, research on the unethical or dark side of luxury has strongly focused on counterfeiting and its effects on brands and consumers (Quach and Thaichon 2018).

\section{Discussion}

The existence of luxury can be traced back to the dawn of humanity, and since then, it has been an intrinsic part of society (Cristini et al. 2017). With the new millennium, luxury has evolved in meaning and nature. For baby boomers and Generation X, luxury was about the show of riches and materialistic possession of the most exquisite and tailored products. As the world accepts luxury's contemporary version, global consensus on environmental protection, changing customer segments, and new markets beyond the West, newer luxury concepts are coming to the fore. This paper contributes to understanding LM and gauging the emergence of these new themes, non-existent until the onset of the twenty-first century. By addressing the proposed research questions, this study systematically maps LM research for 34 years and sheds light on the evolution and future of the field.

\section{Theoretical implications}

This review expects to make distinctive contributions to luxury theory by advancing the discourse toward a contemporary vision. We aim to add to previous reviews and make the dialogue futuristic for scholars. We advance the scholarship in several ways: first, we acknowledged the structural questions through bibliographic coupling, ideally suited to identify the knowledge base and intellectual structures (Snyder 2019). None of the previous reviews have used bibliographic coupling, argued to represent a research area more accurately (Zupic and Cater 2015), and significantly helpful in mapping research fronts. It is becoming a preferential method to map emerging sub-themes (Glanzel and Thijs 2012).

Second, although research foundations were laid on understanding luxury from a cross-disciplinary perspective, work is needed to capture a comprehensive LM view. Following our analysis, a major theoretical contribution is proposing a conceptual framework canvassing LM holistically through an integrative approach to bridge this gap. Past frameworks contribute a descriptive understanding of luxury. But considering the major developments, scholars need a more futuristic framework leading to progressive dialogues. Our framework linking various cluster themes should advance the field by understanding the current structure of knowledge and further opening a discourse on the continuance of research by providing an elaborate future research pathway. Researchers appreciate this shift and ground their research into broader and deeper aspects of LM. However, most research focuses on luxury fashion, jewelry, and accessories (Grotts and Johnson 2013; Mainolfi 2020). Higher involvement categories like luxury houses, cars, and yachts have not been explored as much. Luxury goods have received considerable scholarly attention, but services are sparsely researched. It is only recently that Wirtz et al. (2020) conceptualized luxury services. However, there is immense scope for grounding service theories and conceptual frameworks. The corpus also highlights darker aspects of this industry. However, only consumer knowledge 
(Musnaini et al. 2017), purchase intention (Bakhshian et al. 2019), and its impact on the brand image (Perez et al. 2010) have been investigated for almost a decade. Moreover, a new form of online counterfeiting still requires academic backing.

Third, despite the extensive availability of knowledge, we observe a gap in selecting sources capturing the field's multidimensionality. Considering the criteria adopted for article selection, we anticipate that relevant research has been overlooked. Instead of a small number of pre-selected sources, this study identifies all available articles, generating a robust database, thus limiting researcher's selection bias (Veloutsou and Mafe 2020).

Finally, after comprehensively identifying the research outputs, we take a step ahead by using a semi-systematic, integrative approach, contrary to previous reviews, as it is a highly effective method of covering broad research and wider topics (Snyder 2019). Collectively, our theoretical contribution through a conceptual model weaves the LM literature together and paves the way for further investigation into each thematic cluster.

\section{Managerial implications}

An assessment of the theoretical structure paves the way for luxury brand managers to delve deep into the landscape and curate fresh perspectives yet maintaining the luxury aura. Luxury is not confined to engaging customers through advertising to generate sales. Instead, it is an ecosystem that empowers brands and consumers to come together and cocreate value and experiences (Tynan et al. 2010).

This consumer proximity raises branding issues, primarily on two fronts. At one end, luxury brands are expected to showcase environmental sensitivity and be flagbearers of sustainability. Thus, brands focus on communicating the 'causes' they stand for, sustainability included, while creating extreme customer value. Heritage luxury brands like Louis Vuitton and Prada, are excellent examples of communicating their sustainability and CSR initiatives through digital channels.

The other is becoming a swift adopter of technology to provide an unparalleled customer experience. This is not limited to providing personalized e-mail messages or making the retail store experience effortless and memorable. It also extends to the online shopping experience with the new tech-savvy generation wanting brands to convey their values unequivocally in an omnichannel environment.

Gen $\mathrm{Z}$ and millennials differ from their older counterparts and have distinct value systems. Instead of materialistic possessions, experience is the cornerstone of this newer segment (Atwal and Williams 2017) that need not be confined to flagship stores. Interactive websites leveraging smart technologies like AI offer two-fold benefits of effectively providing a flawless omnichannel experience while enabling brands to gather real-time customer data for better experience curation.

Most luxury brands have leveraged globalization and have moved out of their home countries. Emerging Asian markets are lucrative for European and American brands. However, managers of heritage luxury brands must be equally considerate of their local consumers. Cultural differences might entice brands into making a strategic shift. This should not hurt home consumers.

Another important implication arises from shifting consumer demographics leading to new business models. These include collaborative consumption, sharing, renting, and secondhand luxury. While the intent was promoting circular fashion, it is often misused. Many peer-to-peer selling enterprises claiming to show environmental concern often end up reducing luxury brands' deadlock burden by offering unsold inventory in the name of secondhand. This threatens brand image. Thus, managers should re-look their strategies by actively engaging in circular consumption and considering alters in consumer behavior, else they may invite criticism. Sustainable re-sale is still a big question for luxury brands to pull through effectively.

Darker aspects like counterfeiting are long existent but have moved boundaries. Contemporary forms include fake products in the online space where social media pages sell first copies. Brand managers should pay attention to digital platforms misusing consumer trust. Curating online communication to enhance product knowledge and protect customers from fake sellers is paramount.

Conspicuousness considered as luxury's heart and soul for decades, is declining. Instead, new minimalist and less materialistic luxuries, where consumers seek spirituality and happiness, are gaining popularity. Therefore, brands should pay attention to this aspect, curating experiences and values relevant for this segment.

\section{Limitations}

Although the study is detailed in its approach, it has some limitations. First, it is limited to the broad view of luxury marketing and terminates on suggesting future research for each cluster. An in-depth analysis of each cluster theme can be taken up in the future with the sole focus on specific literature like counterfeiting or luxury social media. Second, the bibliometric method does not perform a full-text analysis. Instead, it only considers title and keywords. Future research could use big data tools to overcome this while subjectively identifying thematic clusters. 


\section{Appendix 1: Future research questions emerging from clusters}

\begin{tabular}{|c|c|c|}
\hline Cluster & Cluster name & Research Questions \\
\hline 1 & Responsible luxury & $\begin{array}{l}\text { RQ1. What are the perceived risks for consumers while indulging in collaborative consumption } \\
\text { applications? } \\
\text { RQ2. Are Asian luxury consumers open to pre-loved luxury like their western counterparts? } \\
\text { RQ3.How do luxury brands overcome mismatches with CSR? Which CSR strategies work and } \\
\text { do not work for luxury brands? } \\
\text { RQ4. How should luxury brands communicate ethical/sustainable luxury to customers? } \\
\text { RQ5. What are the factors that facilitate the acceptance and furtherance of ethicality/sustainabil- } \\
\text { ity luxury? } \\
\text { RQ6. How effective are green and cause-related marketing strategies for luxury brands? How } \\
\text { should brands communicate the "purpose" they stand for? }\end{array}$ \\
\hline 2 & $\begin{array}{l}\text { Luxury consumer } \\
\text { behavior }\end{array}$ & $\begin{array}{l}\text { RQ7. How are luxury consumers spread within Asia? What cultural differences exist between } \\
\text { China, Japan, Korea, India, etc., that distinguish them from the West? } \\
\text { RQ8. How do consumers respond to luxury services differently than tangible products? How } \\
\text { does communication vary across categories? } \\
\text { RQ9. How do luxury brands ensure maximum customer value across all touchpoints in } \\
\text { omnichannel retail? } \\
\text { RQ10. How is the millennial segment as a luxury consumer? What marketing techniques work or } \\
\text { do not work on them? } \\
\text { RQ11. How do different consumer segments respond to the use of technology in marketing? }\end{array}$ \\
\hline 3 & $\begin{array}{l}\text { Luxury brand manage- } \\
\text { ment }\end{array}$ & $\begin{array}{l}\text { RQ12. What are the implications of digital branding for heritage luxury brands? } \\
\text { RQ13. What strategies should luxury brands adopt while communicating through digital touch- } \\
\text { points? } \\
\text { RQ14. How should luxury brands curate seamless and integrated customer journey experience in } \\
\text { an omnichannel environment? } \\
\text { RQ15. In an integrated digital environment where everything is available online, how should } \\
\text { luxury brands limit or control the messages to ensure safety? } \\
\text { RQ16. How should brands maintain stewardship in shifting consumer cultures and keep pace } \\
\text { with emerging technologies? } \\
\text { RQ17. What are the implications for luxury collaborations with distinct product categories like } \\
\text { activewear? }\end{array}$ \\
\hline 4 & $\begin{array}{l}\text { Social media market- } \\
\text { ing }\end{array}$ & $\begin{array}{l}\text { RQ18. How important a role do social media influencers play for luxury brands? } \\
\text { RQ19. How are social media marketing strategies different from traditional marketing strategies? } \\
\text { What works, what does not? } \\
\text { RQ20. How do smart technologies like AI, AR, VR, IoT change the way social media marketing } \\
\text { and advertising is done for luxury brands? } \\
\text { RQ21. How is real-time consumer data generated through social media and other online plat- } \\
\text { forms helping luxury brands? } \\
\text { RQ22. How do both brands and consumers see live streaming of fashion events and luxury prod- } \\
\text { uct launches? } \\
\text { RQ23. How are western brands drawing a line between social media communication to stay } \\
\text { relevant both in their home country and the Asian markets? }\end{array}$ \\
\hline 5 & $\begin{array}{l}\text { Conspicuous consump- } \\
\text { tion }\end{array}$ & $\begin{array}{l}\text { RQ24. How do consumers display wealth while consuming luxury services? How does intangible } \\
\text { service consumption display conspicuous behavior? } \\
\text { RQ25. How important is inconspicuousness for luxury? } \\
\text { RQ26. How are minimalism and spirituality affecting the conspicuous nature of luxury? }\end{array}$ \\
\hline 6 & $\begin{array}{l}\text { Customer perceived } \\
\text { value }\end{array}$ & $\begin{array}{l}\text { RQ27. What role does technology play in integrating value for both customer and the luxury } \\
\text { brand? } \\
\text { RQ28. How do value perceptions change while purchasing secondhand luxury goods? } \\
\text { RQ29. What dimensions of value perceptions are dominant during luxury rentals? } \\
\text { RQ30. In a service-based setting, how do AI and other smart tools govern customer decision- } \\
\text { making? }\end{array}$ \\
\hline
\end{tabular}




\begin{tabular}{ll}
\hline Cluster & Cluster name \\
\hline 7 & Research Questions \\
& RQ31. How can luxury brands cope with fake products? \\
& RQ32. In an online market for luxury goods, what knowledge should consumers possess while \\
buying luxury items? & RQ33. How can counterfeiting be curbed on third-party online selling websites? Do brands hold \\
control? & RQ34. How do millennials respond to counterfeiting? Do they voluntarily indulge in such pur- \\
chases to show status, or the unawareness is helping this market prosper? \\
RQ35. Can technology help consumers to identify a luxury product's authenticity?
\end{tabular}

\section{Declarations}

Conflict of interest The authors declare no conflict of interest whatsoever.

\section{References}

Adomaitis, A. D. and Saiki, D. 2019. Brand personality and sexuality levels of luxury advertisements. Journal of Fashion Marketing and Management: An International Journal.

Aksoy, H. and Abdulfatai, O. Y. 2019. Exploring the impact of religiousness and culture on luxury fashion goods purchasing intention. Journal of Islamic Marketing.

AlRyalat, S.A.S., L.W. Malkawi, and S.M. Momani. 2019. Comparing bibliometric analysis using PubMed, Scopus, and Web of Science databases. JoVE (journal of Visualized Experiments) 152: e58494.

Aliyev, F., and R. Wagner. 2018. Cultural influence on luxury value perceptions: Collectivist vs. individualist luxury perceptions. Journal of International Consumer Marketing 30(3): 158-172.

Andrus, D. M., Silver, E. and Johnson, D. E. 1986. Status brand management and gift.

Arli, D., Cherrier, H. and Tjiptono, F. 2016. God blesses those who wear Prada. Marketing Intelligence \& Planning.

Arli, D., L.D.A. Gil, and P. van Esch. 2020. The effect of religiosity on luxury goods: The case of Chilean youths. International Journal of Consumer Studies 44(3): 181-190.

Atwal, G. and Williams, A. 2017. Luxury brand marketing-the experience is everything!. In Advances in luxury brand management, 43-57. Cham: Palgrave Macmillan.

Audrin, C., T. Brosch, D. Sander, and J. Chanal. 2018. More than meets the eye: The impact of materialism on information selection during luxury choices. Frontiers in Behavioral Neuroscience 12: 172.

Banerjee, S. and Pal, A. 2020. Luxury Hotel Booking and Scarcity Messages: Does Online Purchase Behavior Matter?. In 2020 6th International Conference on Information Management (ICIM), 101-105. IEEE.

Baas, J., M. Schotten, A. Plume, G. Côté, and R. Karimi. 2020. Scopus as a curated, high-quality bibliometric data source for academic research in quantitative science studies. Quantitative Science Studies 1(1): 377-386.

Baghi, I. and Gabrielli, V. 2018. Brand prominence in cause-related marketing: luxury versus non-luxury. Journal of Product \& Brand Management.

Bakhshian, S., Y.A. Lee, and W. Cao. 2019. Psycho-Demographic Determinants of Young Consumers' Purchase Intention toward
Counterfeit Apparel in a US Counterfeit Capital. Family and Consumer Sciences Research Journal 47(4): 324-341.

Bardhi, F., Eckhardt, G. M. and Samsioe, E. 2020. Liquid luxury. In Research Handbook on Luxury Branding. Edward Elgar Publishing.

Bartikowski, B., F. Fastoso, and H. Gierl. 2019. Luxury cars Made-inChina: Consequences for brand positioning. Journal of Business Research 102: 288-297.

Batat, W. 2019. The New Experiential Luxury Marketing Model. In The New Luxury Experience, 33-53. Cham: Springer.

Becker, K., J.W. Lee, and H.M. Nobre. 2018. The concept of luxury brands and the relationship between consumer and luxury brands. Journal of Asian Finance, Economics and Business 5(3): 51-63.

Berry, C.J. 1994. The idea of luxury: A conceptual and historical investigation, vol. 30. Cambridge University Press.

Berthon, P., L. Pitt, M. Parent, and J.P. Berthon. 2009. Aesthetics and ephemerality: Observing and preserving the luxury brand. California Management Review 52(1): 45-66.

Bian, X., K.Y. Wang, A. Smith, and N. Yannopoulou. 2016. New insights into unethical counterfeit consumption. Journal of Business Research 69(10): 4249-4258.

Blasi, S., L. Brigato, and S.R. Sedita. 2020. Eco-friendliness and fashion perceptual attributes of fashion brands: An analysis of consumers' perceptions based on twitter data mining. Journal of Cleaner Production 244: 118701.

Block, J. and Fisch, C. 2020. Eight tips and questions for your bibliographic study in business and management research. Management Review Quarterly.

Boenigk, S., and V. Schuchardt. 2015. Nonprofit collaboration with luxury brands: Positive and negative effects for cause-related marketing. Nonprofit and Voluntary Sector Quarterly 44(4): $708-733$

Boisvert, J., and N.J. Ashill. 2018. The spillover effect of downward line extensions on US consumers' evaluation of a French luxury parent brand: The role of branding strategies, authenticity, and fit. Psychology \& Marketing 35(10): 740-751.

Brun, A., Castelli, C. M., Hennigs, N., Wiedmann, K. P., Klarmann, C. and Behrens, S. 2015. The complexity of value in the luxury industry. International Journal of Retail \& Distribution Management.

Bryson, D., Atwal, G. and Hultén, P. 2013. Towards the conceptualisation of the antecedents of extreme negative affect towards luxury brands. Qualitative Market Research: An International Journal.

Chao, A., and J.B. Schor. 1998. Empirical tests of status consumption: Evidence from women's cosmetics. Journal of Economic Psychology 19(1): 107-131.

Chen, J., and S. Kim. 2013. A comparison of Chinese consumers' intentions to purchase luxury fashion brands for self-use and for gifts. Journal of International Consumer Marketing 25(1): $29-44$. 
Choo, H. J., Moon, H., Kim, H. and Yoon, N. 2012. Luxury customer value. Journal of Fashion Marketing and Management: An International Journal.

Cristini, H., H. Kauppinen-Räisänen, M. Barthod-Prothade, and A. Woodside. 2017. Toward a general theory of luxury: Advancing from workbench definitions and theoretical transformations. Journal of Business Research 70: 101-107.

Correia, A., M. Kozak, and G. Del Chiappa. 2020. Examining the meaning of luxury in tourism: A mixed-method approach. Current Issues in Tourism 23(8): 952-970.

Coudounaris, D. N. 2018. Mediation of product design and moderating effects of reference groups in the context of country-of-origin effect of a luxury brand. Review of International Business and Strategy.

Das, M., and C. Jebarajakirthy. 2020. Impact of acculturation to western culture (AWC) on western fashion luxury consumption among Gen-Y consumers in the Asia-Pacific region. Journal of Retailing and Consumer Services 56: 102179.

Ding, W., M. Pandelaere, H. Slabbinck, and D.E. Sprott. 2020. Conspicuous gifting: When and why women (do not) appreciate men's romantic luxury gifts. Journal of Experimental Social Psychology 87: 103945.

Dogan-Sudas, H., A. Kara, and S. Cabuk. 2019. The role of sustainable environment attributes in luxury product perceptions: Evidence from an emerging market. Journal of Transnational Management 24(1): 3-20.

Donthu, N., Kumar, S., Pandey, N. and Soni, G. 2020. A retrospective overview of Asia Pacific Journal of Marketing and Logistics using a bibliometric analysis. Asia Pacific Journal of Marketing and Logistics.

Donzé, P.Y. 2020. The transformation of global luxury brands: The case of the Swiss watch company Longines, 1880-2010. Business History 62(1): 26-41.

Fazeli, Z., P. Shukla, and K. Perks. 2020. Digital buying behavior: The role of regulatory fit and self-construal in online luxury goods purchase intentions. Psychology \& Marketing 37(1): 15-26.

Garín-Mun, T. 2006. Inbound international tourism to Canary Islands: A dynamic panel data model. Tourism Management 27(2): 281-291.

Gensler, S., F. Völckner, Y. Liu-Thompkins, and C. Wiertz. 2013. Managing brands in the social media environment. Journal of Interactive Marketing 27(4): 242-256.

Gentina, E., L.J. Shrum, and T.M. Lowrey. 2016. Teen attitudes toward luxury fashion brands from a social identity perspective: A crosscultural study of French and US teenagers. Journal of Business Research 69(12): 5785-5792.

Glänzel, W., and B. Thijs. 2012. Using 'core documents' for detecting and labelling new emerging topics. Scientometrics 91(2): 399-416.

Godey, B., A. Manthiou, D. Pederzoli, J. Rokka, G. Aiello, R. Donvito, and R. Singh. 2016 Social media marketing efforts of luxury brands: Influence on brand equity and consumer behavior. Journal of business research 69(12): 5833-5841.

Gurzki, H., N. Schlatter, and D.M. Woisetschläger. 2019. Crafting extraordinary stories: Decoding luxury brand communications. Journal of Advertising 48(4): 401-414.

Gurzki, H., and D.M. Woisetschläger. 2017. Mapping the luxury research landscape: A bibliometric citation analysis. Journal of Business Research 77: 147-166.

Guzmán, F., Abimbola, T., Tolba, A. H. and Hassan, S. S. 2009. Linking customer-based brand equity with brand market performance: a managerial approach. Journal of Product \& Brand Management.

Grotts, A. S. and Johnson, T. W. 2013. Millennial consumers' status consumption of handbags. Journal of Fashion Marketing and Management: An International Journal.
Hasbullah, N.N., Z. Sulaiman, and Mas'od, A. 2020. User-generated content sources: The use of social media in motivating sustainable luxury fashion consumptions. International Journal of Scientific and Technology Research 9(3): 5208-5214.

Heine, K. 2010. The personality of luxury fashion brands. Journal of Global Fashion Marketing 1(3): 154-163.

Heine, K., G. Atwal, S. Crener-Ricard, and M. Phan. 2018. Personalitydriven luxury brand management. Journal of Brand Management 25(5): 474-487.

Hodge, A.C., Z.G. Romo, I.G. Medina, and A. Fionda-Douglas. 2015. Consumer-brand relationships within the luxury cosmetic domain. Journal of Brand Management 22(8): 631-657.

Holmqvist, J., C.D. Ruiz, and L. Peñaloza. 2020. Moments of luxury: Hedonic escapism as a luxury experience. Journal of Business Research 116: 503-513.

Hudders, L., and M. Pandelaere. 2012. The silver lining of materialism: The impact of luxury consumption on subjective well-being. Journal of Happiness Studies 13(3): 411-437.

Hung, K.P., A.H. Chen, N. Peng, C. Hackley, R.A. Tiwsakul, and C.L. Chou (2011) Antecedents of luxury brand purchase intention. Journal of Product \& Brand Management.

Iglesias, O., Singh, J. J., Casabayó, M., Hung, K. P., Chen, A. H., Peng, N., and Chou, C. L. 2011. Antecedents of luxury brand purchase intention. Journal of Product \& Brand Management.

Jain, S., and S. Mishra. 2020. Luxury fashion consumption in sharing economy: A study of Indian millennials. Journal of Global Fashion Marketing 11(2): 171-189.

Jain, V. 2018. Luxury: Not for consumption but developing extended digital self. Journal of Human Values 24(1): 25-38.

Jain, V., and D.E. Schultz. 2019. How digital platforms influence luxury purchase behavior in India? Journal of Marketing Communications 25(1): 41-64.

Jebarajakirthy, C., Yadav, R. and Shankar, A. 2020. Insights for luxury retailers to reach customers globally. Marketing Intelligence \& Planning.

Jhamb, D., Aggarwal, A., Mittal, A. and Paul, J. 2020. Experience and attitude towards luxury brands consumption in an emerging market. European Business Review.

Jin, S. V. and Ryu, E. 2019. Instagram fashionistas, luxury visual image strategies and vanity. Journal of Product \& Brand Management.

Jin, Y.J., S.C. Park, and J.W. Yoo. 2017. Effects of corporate social responsibility on consumer credibility perception and attitude toward luxury brands. Social Behavior and Personality: An International Journal 45(5): 795-808.

Kapferer, J. N. and Bastien, V. 2017. The specificity of luxury management: Turning marketing upside down. In Advances in luxury brand management, 65-84. Cham: Palgrave Macmillan.

Kapferer, J.N., and A. Michaut-Denizeau. 2020. Are millennials really more sensitive to sustainable luxury? A cross-generational international comparison of sustainability consciousness when buying luxury. Journal of Brand Management 27(1): 35-47.

Karatzas, S., A. Kapoulas, and C.V. Priporas. 2019. Consumers' perceptions on complexity and prospects of ethical luxury: Qualitative insights from Taiwan. Australasian Marketing Journal (AMJ) 27(4): 224-232.

Kastanakis, M.N., and G. Balabanis. 2012. Between the mass and the class: Antecedents of the "bandwagon" luxury consumption behavior. Journal of Business Research 65(10): 1399-1407.

Keller, K. L. 2017. Managing the growth tradeoff: Challenges and opportunities in luxury branding. In Advances in luxury brand management, 179-198. Cham: Palgrave Macmillan.

Ki, C.W., and Y.K. Kim. 2016. Sustainable versus conspicuous luxury fashion purchase: Applying self-determination theory. Family and Consumer Sciences Research Journal 44(3): 309-323. 
Kim, A.J., and E. Ko. 2012. Do social media marketing activities enhance customer equity? An empirical study of luxury fashion brand. Journal of Business Research 65(10): 1480-1486.

Kim, J., Kang, S. and Lee, K. H. 2019. Evolution of digital marketing communication: Bibliometric analysis and network visualization from key articles. Journal of Business Research.

Kim, S., S. Lee, J.H. Lee, and C.R. Taylor. 2020. Can premium private labels compete with luxury brands: The impact of advertising on perceived luxuriousness. International Journal of Advertising 39(6): 761-782.

Khan, M. A., Pattnaik, D., Ashraf, R., Ali, I., Kumar, S. and Donthu, N. (forthcoming). Value of special issues in the journal of business research: A bibliometric analysis. Journal of Business Research. https://www.sciencedirect.com/science/article/abs/pii/S0148 296320308444

Ko, E., J.P. Costello, and C.R. Taylor. 2019. What is a luxury brand? A new definition and review of the literature. Journal of Business Research 99: 405-413.

Kotler, P., G. Chandler, L. Brown, and S. Adam. 1994. Marketing Australia and New Zealand, 269. Sydney: Prentice Hall.

Kruggel, A., V. Tiberius, and M. Fabro. 2020. Corporate citizenship: Structuring the research field. Sustainability 12(13): 5289.

Kusumasondjaja, S. 2019. Exploring the role of visual aesthetics and presentation modality in luxury fashion brand communication on Instagram. Journal of Fashion Marketing and Management: An International Journal.

Liu, S., P. Perry, C. Moore, and G. Warnaby. 2016. The standardization-localization dilemma of brand communications for luxury fashion retailers' internationalization into China. Journal of Business Research 69(1): 357-364.

Loureiro, S.M.C., M.A.P. De Plaza, and M. Taghian. 2020. The effect of benign and malicious envies on desire to buy luxury fashion items. Journal of Retailing and Consumer Services 52: 101688.

Madinga, N.W., E.T. Maziriri, and T. Lose. 2016. Exploring status consumption in South Africa: a literature review. Investment Management and Financial Innovations 13(3): 131-136.

Mainolfi, G. 2020. Exploring materialistic bandwagon behaviour in online fashion consumption: A survey of Chinese luxury consumers. Journal of Business Research 120: 286-293.

Massara, F., D. Scarpi, and D. Porcheddu. 2020. Can your advertisement go abstract without affecting willingness to pay?: Productcentered versus lifestyle content in luxury brand print advertisements. Journal of Advertising Research 60(1): 28-37.

Miller, K.W., and M.K. Mills. 2012. Probing brand luxury: A multiple lens approach. Journal of Brand Management 20(1): 41-51.

Miskiewicz, R. 2020. Internet of Things in Marketing: Bibliometric Analysis.

Mititelu, C., G. Fiorani, and S. Mariani. 2014. Cause related marketing: Armani initiative 'acqua for life.' International Review on Public and Nonprofit Marketing 11(3): 285-305.

Monga, A.B., and D.R. John. 2010. What makes brands elastic? The influence of brand concept and styles of thinking on brand extension evaluation. Journal of Marketing 74(3): 80-92.

Musnaini, M., S.W. Astuti, B.M. Sukoco, and S. Yacob. 2017. Effect of hedonic value and consumer knowledge on buying intention for luxury brand counterfeit products. International Journal of Business and Globalisation 19(4): 497-511.

Nelissen, R.M., and M.H. Meijers. 2011. Social benefits of luxury brands as costly signals of wealth and status. Evolution and Human Behavior 32(5): 343-355.

Ngai, J. and Cho, E. 2012. The young luxury consumers in China. Young Consumers.

Nia, A. and Zaichkowsky, J. L. 2000. Do counterfeits devalue the ownership of luxury brands?. Journal of Product \& Brand Management.
Nyadzayo, M. W., Johnson, L. W. and Rossi, M. 2020. Drivers and outcomes of brand engagement in self-concept for luxury fashion brands. Journal of Fashion Marketing and Management: An International Journal.

O'cass, A. and Frost, H. 2002. Status brands: examining the effects of non-product-related brand associations on status and conspicuous consumption. Journal of Product \& Brand Management.

O'Cass, A. and Siahtiri, V. 2014. Are young adult Chinese status and fashion clothing brand conscious?. Journal of Fashion Marketing and Management.

Oswald, L. 2010. Developing brand literacy among affluent Chinese consumers: A semiotic perspective. ACR North American Advances.

Pantano, E., and N. Stylos. 2020. The Cinderella moment: Exploring consumers' motivations to engage with renting as collaborative luxury consumption mode. Psychology \& Marketing 37(5): 740-753.

Park, S.Y., and M.Y.C. Yim. 2020. Do celebrity endorsements benefit familiar luxury brands? A perspective from social adaptation theory. Journal of Current Issues \& Research in Advertising 41(1): 20-35.

Pencarelli, T., V. Ali Taha, V. Škerháková, T. Valentiny, and R. Fedorko. 2020. Luxury products and sustainability issues from the perspective of young Italian consumers. Sustainability 12(1): 245.

Peng, N. 2020. Luxury restaurants' risks when implementing new environmentally friendly programs-evidence from luxury restaurants in Taiwan. International Journal of Contemporary Hospitality Management.

Peng, G., Pu, X. and Ying, X. 2020. Neural Mechanism of How Logos Affect Luxury Purchase Decisions-Insights from Conspicuous Value. In 2020 6th International Conference on Information Management (ICIM), 19-26. IEEE.

Perez, M. E., Castaño, R. and Quintanilla, C. 2010. Constructing identity through the consumption of counterfeit luxury goods. Qualitative Market Research: An International Journal.

Prayag, G., and S. Hosany. 2014. When Middle East meets West: Understanding the motives and perceptions of young tourists from United Arab Emirates. Tourism Management 40: 35-45.

Pritchard, A. 1969. Statistical bibliography or bibliometrics. Journal of Documentation 25(4): 348-349.

Quach, S. and Thaichon, P. 2018. Dark motives-counterfeit selling framework. Marketing Intelligence \& Planning.

Reddy, M., N. Terblanche, L. Pitt, and M. Parent. 2009. How far can luxury brands travel? Avoiding the pitfalls of luxury brand extension. Business Horizons 52(2): 187-197.

Roig-Tierno, N., T.F. Gonzalez-Cruz, and J. Llopis-Martinez. 2017. An overview of qualitative comparative analysis: A bibliometric analysis. Journal of Innovation \& Knowledge 2(1): 15-23.

Rolling, V. and Sadachar, A. 2018. Are sustainable luxury goods a paradox for millennials?. Social Responsibility Journal.

Roper, S., Caruana, R., Medway, D. and Murphy, P. 2013. Constructing luxury brands: exploring the role of consumer discourse. European Journal of Marketing.

Serra, J., A. Correia, and P.M. Rodrigues. 2014. A comparative analysis of tourism destination demand in Portugal. Journal of Destination Marketing \& Management 2(4): 221-227.

Shukla, P. 2010. Status consumption in cross-national context. International Marketing Review.

Skorobogatykh, I.I., O. Saginova, and Z. Musatova. 2014. Comparison of Luxury Brand Perception: Old (UK) vs. Modern (Russia) consumers' perception toward Burberry Brand. Journal of Eastern European and Central Asian Research (JEECAR) 1(1): 7-7.

Snyder, H. 2019. Literature review as a research methodology: An overview and guidelines. Journal of Business Research 104: 333-339. 
Štrach, P. and Everett, A. M. 2006. Brand corrosion: mass-marketing's threat to luxury automobile brands after merger and acquisition. Journal of Product \& Brand Management.

Taplin, I. M. 2016. Crafting an iconic wine: The rise of "cult" Napa. International Journal of Wine Business Research.

Teona, G., E. Ko, and S.J. Kim. 2020. Environmental claims in online video advertising: Effects for fast-fashion and luxury brands. International Journal of Advertising 39(6): 858-887.

Torelli, C.J., A.B. Monga, and A.M. Kaikati. 2012. Doing poorly by doing good: Corporate social responsibility and brand concepts. Journal of Consumer Research 38(5): 948-963.

Tournois, L. and Chanaron, J. J. 2018. Car crisis and renewal: how Mercedes succeeded with the A-Class. Journal of Business Strategy.

Truong, Y., and R. McColl. 2011. Intrinsic motivations, self-esteem, and luxury goods consumption. Journal of Retailing and Consumer Services 18(6): 555-561.

Truong, Y., R. McColl, and P.J. Kitchen. 2009. New luxury brand positioning and the emergence of masstige brands. Journal of Brand Management 16(5-6): 375-382.

Tynan, C., S. McKechnie, and C. Chhuon. 2010. Co-creating value for luxury brands. Journal of Business Research 63(11): 1156-1163.

Üstüner, T., and D.B. Holt. 2010. Toward a theory of status consumption in less industrialized countries. Journal of Consumer Research 37(1): 37-56.

Veloutsou, C., and C.R. Mafe. 2020. Brands as relationship builders in the virtual world: A bibliometric analysis. Electronic Commerce Research and Applications 39: 100901.

Vigneron, F., and L.W. Johnson. 2004. Measuring perceptions of brand luxury. Journal of Brand Management 11(6): 484-506.

Wallin, J.A. 2005. Bibliometric methods: Pitfalls and possibilities. Basic \& Clinical Pharmacology \& Toxicology 97(5): 261-275.

Wang, Y., J.L. Stoner, and D.R. John. 2019. Counterfeit luxury consumption in a social context: The effects on females' moral disengagement and behavior. Journal of Consumer Psychology 29(2): 207-225.

Wang, S.C., P.K. Soesilo, and D. Zhang. 2015. Impact of luxury brand retailer co-branding strategy on potential customers: A crosscultural study. Journal of International Consumer Marketing 27(3): 237-252.

Wiedmann, K.P., N. Hennigs, and A. Siebels. 2009. Value-based segmentation of luxury consumption behavior. Psychology \& Marketing 26(7): 625-651.

Weinberg, B.H. 1974. Bibliographic coupling: A review. Information Storage and Retrieval 10(5-6): 189-196.

Wilcox, K., H.M. Kim, and S. Sen (2009). Why do consumers buy counterfeit luxury brands? Journal of Marketing Research 46(2): 247-259.

Wirtz, J., Holmqvist, J. and Fritze, M. P. 2020. Luxury services. Journal of Service Management (forthcoming).

Wong, N.Y., and A.C. Ahuvia. 1998. Personal taste and family face: Luxury consumption in Confucian and Western societies. Psychology \& Marketing 15(5): 423-441.
Woodside, A.G., and M.B. Fine. 2019. Sustainable fashion themes in luxury brand storytelling: The sustainability fashion research grid. Journal of Global Fashion Marketing 10(2): 111-128.

Wright, L. T., Cova, B. and Pace, S. 2006. Brand community of convenience products: new forms of customer empowermentthe case "my Nutella The Community". European Journal of Marketing.

Yim, M. Y. C., Sauer, P. L., Williams, J., Lee, S. J. and Macrury, I. 2014. Drivers of attitudes toward luxury brands. International Marketing Review.

Yu, D., and S. Sapp. 2019. Motivations of luxury clothing consumption in the US vs. China. Journal of International Consumer Marketing 31(2): 115-129.

Zupic, I., and T. Čater. 2015. Bibliometric methods in management and organization. Organizational Research Methods 18(3): 429-472.

Publisher's Note Springer Nature remains neutral with regard to jurisdictional claims in published maps and institutional affiliations.

Rubal Rathi is a doctoral student at School of Management, BML Munjal University. Her research focuses on hedonic consumption, particularly in the luxury domain. Luxury marketing, brand management, perceived value and customer patronage are some topics that interests her.

Ruchi Garg is an assistant professor at BML Munjal University, Gurgaon. She completed her Fellowship in Management (FPM) from Management Development Institute. Her research interests are Consumer brand relationship, Sensory Marketing, Sustainability Marketing, Luxury Marketing, and consumer behavior.

Aakanksha Kataria is a highly motivated Assistant Professor at the Department of Management Studies, Malaviya National Institute of Technology, Jaipur. She received her Ph.D. in I/O Psychology from the Indian Institute of Technology, Roorkee. She has a unique combination of demonstrated experiences leading multidisciplinary research, teaching, industry exposure, and presenting papers in international conferences. With a genuine passion for I/O Psychology and people management, her research interests include compassion, positive organizational psychology, work engagement, and employee well-being. Her work is published and highlighted in high-quality reputed international journals such as Gender, Work, and Organization, Employee Relations, South Asian Journal of Management, and International Journal of Productivity and Performance.

Ritu Chhikara is Assistant Professor of Marketing and Sustainability at BML Munjal University, Gurugram, India. She has worked in the areas of Sensory Marketing, Sustainable consumer behavior and Omni Channel retailing. 